\title{
Adalimumab for orbital myositis in a patient with Crohn's disease who discontinued infliximab: a case report and review of the literature
}

\author{
Sanam Verma, Karen I Kroeker and Richard N Fedorak
}

\begin{abstract}
Background: Orbital myositis is a rare extra-intestinal manifestation of inflammatory bowel disease. Seventeen cases of Crohn's disease associated orbital myositis and 3 cases of ulcerative colitis associated orbital myositis have been reported in the published literature since 1970. We report the use of adalimumab (Abbott, Canada, Inc.) for orbital myositis in a patient with Crohn's disease who discontinued infliximab (Janssen, Canada, Inc.) and review of the published literature.

Case presentation: A 35 year-old male with a 7-year history of Crohn's disease was treated with an ileocolonic resection and re-anastomosis followed by infliximab which maintained full endoscopic and clinical remission for four years. After stopping the infliximab for infusion-related reactions he presented with 3-day history of severe right eye pain, pain with ocular movement, proptosis, and conjunctival injection. He had no intestinal symptoms and endoscopic assessment revealed no active luminal disease. $\mathrm{CT}$ of the orbit revealed an enlarged right medial rectus muscle with tendonous involvement and a diagnosis of orbital myositis was made. Treatment with $80 \mathrm{mg}$ per day prednisone with tapering dose and adalimumab, induction and maintenance, resulted in rapid resolution of the orbital myositis and ocular symptoms with no recurrences on follow-up at 10 months.
\end{abstract}

Conclusions: The current case demonstrates a rare extraintestinal manifestation of Crohn's disease, orbital myositis, and its temporal relationship to the discontinuance of infliximab therapy and its successful treatment, without recurrence with tapering prednisone and adalimumab.

Keywords: Crohn's disease, Ulcerative colitis, Orbital myositis, Extraintestinal manifestations, Inflammatory bowel disease, Infliximab, Adalimumab

\section{Background}

Extra-intestinal manifestations of Crohn's disease (CD) are inflammatory manifestations that occur outside the gastrointestinal tract. Up to 30\% of Crohn's patients may present with multiple extraintestinal manifestations with the occurrence of one increasing the chances of others [1]. Ocular manifestations of CD occur infrequently with a prevalence rate of less than 10\%; most of these cases being episcleritis and uveitis [2]. Orbital myositis (OM) is a very rare ocular extraintestinal manifestation of $C D$.

A literature review revealed that in a sample of $498 \mathrm{pa}-$ tients with Crohn's only one patient had OM [3]. To

\footnotetext{
* Correspondence: richard.fedorak@ualberta.ca

Division of Gastroenterology, University of Alberta, Zeidler Ledcor Center, Edmonton, Alberta, Canada T6G 2X8
}

determine the full published literature relating to $\mathrm{OM}$ as a complication of CD the PubMed and Medline databases were searched for relevant literature. Seventeen previous cases of Crohn's related OM have been reported in literature. Only one previous study looked at adalimumab use in recurrent $\mathrm{OM}$ related to $\mathrm{CD}$ [4-9]. Therefore, in this patient group the use of adalimumab needs to be further explored.

\section{Case presentation}

A 35-year-old Caucasian male was diagnosed with long segment ileal and extensive colonic CD in 2005, following a 10-year history of intermittent abdominal pain, cramps, and diarrhea. At diagnosis patient was placed on mesalamine ( $4 \mathrm{~g} / \mathrm{d}$ ), corticosteroids (prednisone $40 \mathrm{mg} / \mathrm{d}$ tapering over 12 weeks to zero) and azathioprine $(150 \mathrm{mg} / \mathrm{d})$ as induction therapy. He achieved clinical

\section{Biomed Central}




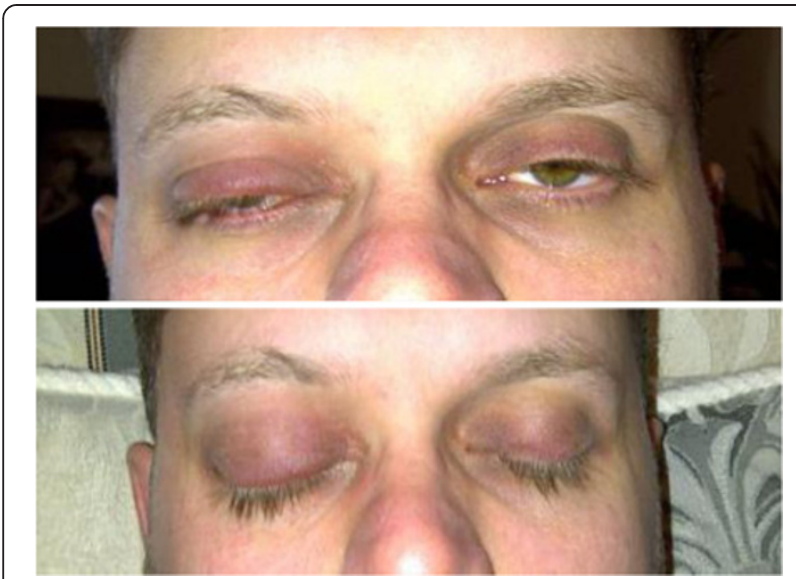

Figure 1 Patient at presentation with erythema and edema of the right upper eyelids, fullness of superior sulcus suggestive of proptosis.

remission; however, within 8 months he developed an episode of small bowel obstruction and underwent an ileal resection with an ileocolonic anastomosis.

Post operatively he was treated with azathioprine $150 \mathrm{mg} / \mathrm{d}$; however, markedly elevated liver enzymes led to the discontinuance of the azathioprine. Within 6 months of stopping the azathioprine he developed recurrent abdominal pain and diarrhea and colonoscopy confirmed anastomotic recurrence of his disease. He was then started on infliximab $(5 \mathrm{mg} / \mathrm{kg})$ monotherapy with an induction regime of $0,2,6$ weeks followed by maintenance treatment every 8 weeks. He achieved a full remission, confirmed endoscopically, for four years.
After his $28^{\text {th }}$ infliximab infusion, he began to develop significant arthralgia and maculaopapular skin rashes on the dorsum of his hands and arms, which worsened after each infliximab infusion. There was no biochemical evidence of disease activity; hemoglobin, C-reactive protein, platelet count, serum iron and ferritin were normal. The infliximab was discontinued and endoscopic restaging and assessment for adalimumab insurance coverage was arranged. 6-mercaptopurine $(75 \mathrm{mg} / \mathrm{d})$ was started after discontinuation of the inflximab while the endoscopic restaging and assessment was pending. However, the 6-mercaptopurine was stopped after 3 weeks due to severe nausea and fatigue. The patient's occupation prevented him from completing the restaging and insurance assessment and during this time he was on no therapy for his CD.

Six weeks after stopping the 6-mercaptopurine and 13 weeks after stopping the infliximab the patient presented to the emergency department with a three-day history of severe right eye pain. Examination revealed an uncorrected visual acuity was 20/25 OD and 20/20 OS. Intraocular pressure of the right eye was slightly elevated, the right upper eyelid was swollen and the conjunctiva injected (Figure 1). The right globe was $1.5 \mathrm{~mm}$ anterior than the left. Pupillary response to light was normal and there was no relative afferent pupillary defect. The patient had limited extraocular movement and significant pain on abduction and adduction of the right eye. No optic nerve abnormalities were noted, specifically no hyperaemia of the optic nerve or nerve fiber layer edema. The patient was afebrile and had normal hemoglobin, white blood cell count, C-reactive protein, iron studies

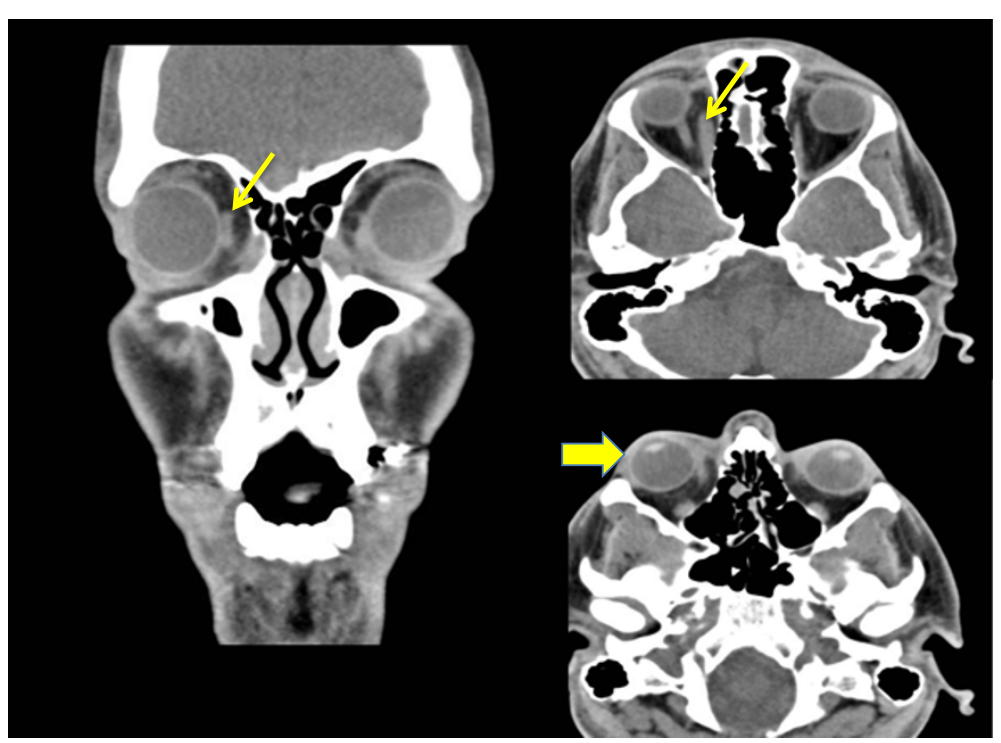

Figure 2 Computerize tomography of the orbits revealed enlarged right medial rectus muscle with tendonous insertion involvement (small arrows) and mild proptosis (large arrow). No fat stranding or scleral thickening was noted. 
and liver function studies. Computerize tomography of the orbits revealed enlarged right medial rectus muscle with tendonous involvement, mild proptosis, no fat stranding or sclerotic changes (Figure 2), and no sinus opacification was noted. The remaining physical exam was normal. Diagnosis of idiopathic orbital inflammatory syndrome, OM subtype, was made based on clinical findings and imaging. The patient was started on prednisone $80 \mathrm{mg} / \mathrm{d}$ and tapered over 4 weeks. Within 48 hours there was improvement in the orbital pain, redness, and swelling and the patient was then started on adalimumab with induction dosing of $160 \mathrm{mg}, 80 \mathrm{mg}$, followed by $40 \mathrm{mg}$ weekly and methotrexate $12.5 \mathrm{mg}$ once weekly as a standard combination therapy. Colonoscopy (after initiation of treatment of the $\mathrm{OM}$ ) did not demonstrate active colonic or ileal disease. The OM resolved on the tapering prednisone and adalimumab and the patient has been asymptomatic on adalimumab for 10 months with no recurrence of the OM.

\section{Discussion}

$\mathrm{OM}$ is a very rare extraintestinal manifestation of inflammatory bowel disease and is more common in CD than ulcerative colitis [10]. Seventeen previous cases of $\mathrm{CD}$ associated $\mathrm{OM}$ and three previous cases of $\mathrm{UC}$ related OM have been reported in literature. The clinical specifics related to these published case reports are summarized in Table 1.

$\mathrm{OM}$ is inflammation of one or more extraocular muscles and generally presents with the mass effect of the inflammation, leading to orbital swelling, proptosis, diplopia, chemosis, pain, injection and opthalmoplegia $[12,13]$.

Table 1 Published case reports (1976 - 2012) describing orbital myositis in patients with inflammatory bowel disease

\begin{tabular}{|c|c|c|c|c|c|c|c|}
\hline $\begin{array}{l}\text { Study author/ } \\
\text { year }\end{array}$ & $\begin{array}{l}\text { Age/ } \\
\text { gender }\end{array}$ & $\begin{array}{l}\text { IBD } \\
\text { (CD/UC) }\end{array}$ & $\begin{array}{l}\text { Therpay at time of } \\
\text { orbital myositis }\end{array}$ & $\begin{array}{l}\text { Diagnostic test } \\
\text { confirming orbital } \\
\text { myositis }\end{array}$ & $\begin{array}{l}\text { Treatment for orbital } \\
\text { myositis }\end{array}$ & $\begin{array}{l}\text { Response to } \\
\text { treatment }\end{array}$ & Follow-up \\
\hline Bennion/2012 [10] & $63 \mathrm{M}$ & UC & Infliximab & $C T$ & Infliximab methylprednisone & Resolved & 13 months \\
\hline Pimentel/2012 [9] & $55 \mathrm{~F}$ & CD & Sulfasalazine & Gadolinium MRI & Infliximab prednisolone & Resolved & 24 months \\
\hline $\begin{array}{l}\text { Hernandez-Garfella/ } \\
2011 \text { [6] }\end{array}$ & $32 \mathrm{~F}$ & CD & Corticosteroids & $\mathrm{MRI}$ & Adalimumab & Resolved & 36 months \\
\hline Kondolt/2011 [11] & $11 \mathrm{~F}$ & $C D$ & None & CT MRI & Corticosteroid & Resolved & Unknown \\
\hline Bourikas/2010 [7] & $35 \mathrm{~F}$ & CD & None & $\mathrm{MRI}$ & Steroids & Resolved & 12 months \\
\hline Culver/2008 [4] & $23 \mathrm{~F}$ & CD & Methotrexate Infliximab & Gadolinium MRI & $\begin{array}{l}\text { Methylprednisone } \\
\text { cyclophosphamide }\end{array}$ & $\begin{array}{l}1 \text { recurrent } \\
\text { episode }\end{array}$ & 24 months \\
\hline Ramahlo/2008 [12] & $40 \mathrm{~F}$ & CD & $\begin{array}{l}\text { Methotrexate } \\
\text { 6-mercaptopurine }\end{array}$ & $\mathrm{MRI}$ & Prednisone & Resolved & Unknown \\
\hline Leibovitch/2005 [8] & $44 M$ & CD & Unknown & $C T$ & Prednisolone oral antibiotics & Resolved & 3 months \\
\hline Macarez/2005 [13] & $32 \mathrm{M}$ & UC & Mesalamine & CT MRI & Corticosteroids & Resolved & 12 months \\
\hline Garrity/2004 [14] & $34 \mathrm{~F}$ & CD & Prednisone & $\mathrm{MRI}$ & Infliximab methotrexate & Resolved & 27 months \\
\hline Garrity/2004 [14] & $27 \mathrm{~F}$ & CD & $\begin{array}{l}\text { Prednisone methotrexate } \\
6 \mathrm{MP}\end{array}$ & Unknown & Infliximab & Resolved & 27 months \\
\hline Maalouf/2001 [15] & $48 \mathrm{~F}$ & CD & None & $C T$ & Prednisone & $\begin{array}{l}1 \text { recurrent } \\
\text { episode }\end{array}$ & 96 months \\
\hline Jain/2001 [16] & $43 \mathrm{~F}$ & UC & Unknown & MRI & Corticosteroids & $\begin{array}{l}1 \text { recurrent } \\
\text { episode }\end{array}$ & 8 months \\
\hline Durno/1997 [17] & $12 \mathrm{~F}$ & CD & None & MRI & Prednisone & $\begin{array}{l}3 \text { recurrent } \\
\text { episodes }\end{array}$ & Unknown \\
\hline Squires/1992 [18] & $20 \mathrm{M}$ & $C D$ & None & $C T$ & Prednisone & $\begin{array}{l}1 \text { recurrent } \\
\text { episode }\end{array}$ & Unknown \\
\hline Smith//1992 [19] & $54 \mathrm{~F}$ & CD & Unknown & $C T$ & $\begin{array}{l}\text { Corticosteroid ileocolonic } \\
\text { resection }\end{array}$ & $\begin{array}{l}2 \text { recurrent } \\
\text { episodes }\end{array}$ & 12 months \\
\hline Verbraeken/1984 [20] & $38 \mathrm{~F}$ & CD & Sulfasalazine & Unknown & Coricosteroids Colectomy & Resolved & 2.5 months \\
\hline Weinstein/1984 [21] & $17 \mathrm{~F}$ & CD & None & Unknown & Corticosteroids IV antibiotics & Resolved & 6 months \\
\hline Camfield/1982 [22] & $15 \mathrm{~F}$ & CD & None & Unknown & $\begin{array}{l}\text { Corticosteroids oral } \\
\text { antibiotics ileocolonic } \\
\text { resection }\end{array}$ & $\begin{array}{l}2 \text { recurrent } \\
\text { episodes }\end{array}$ & 3 months \\
\hline Greenstein/1976 [3] & Unknown & $C D$ & Unknown & Unknown & Unknown & Unknown & Unknown \\
\hline
\end{tabular}


The clinical presentation of $\mathrm{CD}$-associated $\mathrm{OM}$ is similar to that of thyroid ophthalmopathy and as such, the pathogenesis needs to be determined early at presentation. Thyroid eye disease is typically bilateral, retracted eyelids, and has more involvement of the inferior and medial rectus while sparing tendonous insertions and appearing spindle shaped on imaging $[10,23]$. In contrast, in OM associated with $\mathrm{CD}$ there is a tubular configuration on imaging reflecting involvement of tendonous insertion [24]. Furthermore, thyroid ophthalmopathy usually does not cause pain as is the case in OM. The pathophysiology of CD associated OM remains unknown, but it has been hypothesized that immune complexes form to antigenic colonic mucoproteins and may cross react with extraocular muscles [21].

OM has been described to occur prior to the development of Crohn's related gastrointestinal symptoms [7], and when the CD is in remission [9]. To our knowledge this is the first case that demonstrates OM occurring in a patient in clinical and biochemical remission after discontinuation of anti-TNF $\alpha$ therapy. The fact that the onset of the OM occurred 13 weeks after stopping infliximab is in keeping with the known infliximab pharmacokinetics [25].

Treatment of CD associated OM has traditionally involved corticosteroids as first line therapy, and low dose orbital radiotherapy, methotrexate, cyclosporine, and cyclophosphamide as second line therapies [26,27]. While the immediate inflammatory phase of $\mathrm{OM}$ is frequently corticosteroid responsive recurrences may occur once the dose is tapered [5]. Indeed, prior to the frequent use of immunosuppressive or anti-TNF $\alpha$ therapy for $\mathrm{CD}$ OM recurrence was common (Table 1). Since the patient in this case report presented with $\mathrm{OM}$ after discontinuation of infliximab, there was significant risk of recurrent $\mathrm{OM}$ once his corticosteroid treatment tapered to zero. Infliximab was used to successfully control chronic recurrent $\mathrm{OM}$ in 4 patients with inflammatory bowel disease (Table 1) and 3 noninflammatory bowel disease patients who all failed standard treatment [14]. Adalimumab was successfully utilized to treat $\mathrm{OM}$ in a single patient with $\mathrm{CD}$ who had recurrent episodes and who failed to respond to standard immunosuppression medication (Table 1) [6] and in one non-inflammatory bowel disease-related case [5]. Mouse chimeric nature of infliximab may lead to the development of autoantibodies and result in blunting of the clinical response and development of adverse reactions. Adalimumab, with a fully humanized molecular structure may not elicit the same autoantibody response. The CARE study efficacy of adalimumab for extraintestinal manifestations of $\mathrm{CD}$ and found that there is no significant difference in EIM resolution based on previous infliximab exposure [28].

\section{Conclusion}

The current case demonstrates a rare extraintestinal manifestation of $\mathrm{CD}, \mathrm{OM}$ and its temporal relationship to the discontinuance of infliximab therapy and its successful treatment, without recurrence (for 10 months at the time of this publication), with tapering prednisone and adalimumab. Clinicians should be cognizant of this rare extraintestinal manifestation of $\mathrm{CD}$ that can occur in the absence of luminal disease activity, its propensity for recurrence and its successful response to anti-TNF $\alpha$ therapy.

\section{Consent statement}

Written informed consent was obtained from the patient for publication of this Case report and any accompanying images. A copy of the written consent is available for review by the Editor of this journal.

\section{Competing interests}

The authors declare that they have no competing interests (both financial and non-financial).

\section{Authors' contribution}

SV involved in drafting and conception of manuscript and acquisition of data. KK made substantial contributions to conception and design, analysis and interpretation of data and critical revision. RF made substantial contributions to conception and design, analysis and interpretation of data, critical revision, given final approval of the version to be published. All authors read and approved the final manuscript.

\section{Acknowledgements}

This work is supported by the Center of Excellence for Gastrointestinal Inflammation and Immunity Research (CEGIIR) and the Cecile Mactaggart gastrointestinal student research fund.

Received: 9 October 2012 Accepted: 25 February 2013

Published: 4 April 2013

\section{References}

1. Caprilli R, Gassull M, Escher JC, Moser G, Munkholm P, et al: European evidence based consensus on the diagnosis and management of Crohn's disease: special situations. Gut March 2006, 55:i36-i58.

2. Mintz R, Feller ER, Bahr RL, Shah SA: Ocular manifestations of inflammatory bowel disease. Inflamm Bowel Dis 2004, 10:135-9.

3. Greenstein AJ, Janowitz HD, Sachar DB: The extra-intestinal complications of Crohn's disease and ulcerative colitis. A study of 700 patients. Medicine (Baltimore) 1976, 55:401-412.

4. Culver EL, Salmon JF, Frith P, Travis SP: Recurrent posterior scleritis and orbital myositis as extra-intestinal manifestations of Crohn's disease: case report and systematic literature review. J Crohns Colitis 2008, 2:337-42.

5. Adams AB, Kazim M, Lehman TJ: Treatment of orbital myositis with Adalimumab (Humira). J Rheumatol 2005, 32:1374-1375.

6. Hernandez-Garfella ML, Garcia AG, Taulet EC, Villanueva CG, Hernandez JM: Adalimumab for recurrent orbital myositis is Crohn's disease: Report of a case with a 3-year follow-up. J Crohns Colitis 2011, 5:265-266.

7. Bourikas LA, Roussomoustakaki M, Papadaki E, Valatas V, Koutroubakis IE, Papadakis KA, et al: A case of orbital myositis preceding the intestinal symptoms of Crohn's disease. J Chrons Colitis 2010, 4:349-50.

8. Leibovitch I, Galanopoulos, Selva D: Suppurative Granulomatous myositis of an extra-ocular muscle in Crohn's disease. American J of Gastroenterology 2005, 100:2136-2137.

9. Pimentel $R$, et al: Recurrent orbital myositis as an extra-intestinal manifestation of Crohn's disease. J Crohns Colitis 2012. doi:10.1016/j. crohns.2012.05.018. 
10. Bennion J, Harris MA, Sivak-Callcott JA, Nguyen J: Bilateral diffuse orbital myositis in a patient with relapsing ulcerative colitis. Ophthal Plast Reconstr Surg 2012, XX(XX).

11. Kondolot M, Unal E, Poyrazoglu G, et al: Orbital myositis associated with focal active colitis in a teenage girl. Childs Nerv Syst 2012, 28:641-643.

12. Ramalho J, Castillo M: Imaging of orbital myositis in Crohn's. Clin Imaging 2008, 32:227-229.

13. Macarez R, Bazin S, Weber F, et al: Orbital myositis associated with ulcerative colitis. J Fr Ophthalmol 2005, 28:610-13.

14. Garrity JA, Coleman AW, Matteson EL, Eggenberger ER, Waitzman DM: Treatment of recalcitrant idiopathic orbital inflammation (chronic orbital myositis) with infliximab. Am J Ophthalmo/ 2004, 138(6):1041-1043.

15. Maalouf T, Angioi K, George JL: Recurrent orbital myositis and Crohn's disease. Orbit 2001, 20(1):75-80

16. Jain S, Gottlob I: Orbital myositis associated with ulcerative colitis. Am J Gastroenterol 2001, 96:3442-4.

17. Durno CA, Ehrlich R, Taylor R, et al: Keeping an eye on Crohn's disease: orbital myositis as the presenting symptom. Can J Gastroenterol 1997, 11(6):497-500.

18. Squires RH, Zwiener RJ, Kennedy RH: Orbital myositis and Crohn's disease. J Paediatr Gastroenterol Nutr 1992, 15:448-451.

19. Smith JW: Orbital pseudotumour and Crohn's disease. Am J Gastroenterol Mar 1992, 87(3):405-406

20. Verbraeken H, Ryckaert S, Demets W: Pseudotumour of the orbit and Crohn's disease. Bull Soc Belge Ophthalmol 1984, 210:65-72.

21. Weinstein JM, Koch K, Lane S: Orbital pseudotumor in Crohn's colitis. Ann Ophthalmol 1984, 16:275-8.

22. Camfield PR, White M, Warner HA, Lythgoe C: Orbital pseudo-tumour and Crohn's disease. J Pediatr 1982, 101:157-158.

23. Durno CA, Ehrlich R, Taylor R, et al: Keeping an eye on Crohn's disease: orbital myositis as the presenting symptom. Can J Gastroenterol 1997, 11:497-500

24. Lacey B, Chang W, Rootman J: Non-thyroid causes of extraocular muscle disease. Surv Ophthalmol 1999, 44:187-213.

25. Rutgeerts $P, D^{\prime}$ Haens $G$, Targan $S$, et al: Efficacy and safety of retreatment with anti-tumor necrosis factor antibody (infliximab) to maintain remission in Crohn's disease. Gastroenterology 1999, 117:761-769.

26. Espinoza GM: Orbital inflammatory pseudotumors: Etiology, differential diagnosis, and management. Curr Rheumatol Rep 2010, 12:443-447.

27. Smith JR, Rosenbaum JT: A role for methotrexate in the management of non-infectious orbital inflammatory disease. $\mathrm{Br} J$ Ophthalmol 2001. 85(10):1220-4.

28. Löfberg R, Louis EV, Reinisch W, Robinson AM, et al: Adalimumab produces clinical remission and reduces extraintestinal manifestations in Crohn's disease: results from CARE. Inflamm Bowel Dis 2012, 18(1):1-9. Epub 2011 Feb 23.

doi:10.1186/1471-230X-13-59

Cite this article as: Verma et al:: Adalimumab for orbital myositis in a patient with Crohn's disease who discontinued infliximab:

a case report and review of the literature. BMC Gastroenterology 2013

$13: 59$

\section{Submit your next manuscript to BioMed Central and take full advantage of:}

- Convenient online submission

- Thorough peer review

- No space constraints or color figure charges

- Immediate publication on acceptance

- Inclusion in PubMed, CAS, Scopus and Google Scholar

- Research which is freely available for redistribution 